\title{
Characterization of the 1,3- $\beta$-glucan synthase of Aspergillus fumigatus
}

\author{
A. Beauvais, ${ }^{1 *}$ R. Drake,${ }^{2}$ K. NG,${ }^{3}$ M. Diaquin ${ }^{1}$ and J. P. Latgé ${ }^{1}$ \\ ${ }^{1}$ Unité de Mycologie, Institut Pasteur, 25 rue du Dr Roux, 75015 Paris, France \\ ${ }^{2}$ Department of Biochemistry and Molecular Biology, University of Arkansas, Slot 516, 4301 W, Markham Little \\ Rock, Arkansas 72205-7199, USA \\ ${ }^{3}$ The Walter and Eleza Hall Institute of Medical Research, Royal Melbourne Hospital, Victoria 3050, Australia
}

(Received 21 June 1993; revised 30 August 1993; accepted 2 September 1993)

\begin{abstract}
$1,3-\beta$-Glucan synthase activity has been detected in a membrane fraction extracted from the mycelium of the filamentous fungus Aspergillus fumigatus. The enzyme was solubilized by CHAPS and stabilized by filtration on a Bio-gel P30 column. Highest activity was obtained in the early exponential phase of growth. Four factors - GTP, $\mathrm{NaF}$, sucrose and EDTA - added during the extraction procedure, were essential for optimal 1,3- $\beta$-glucan synthase activity. The soluble enzyme preparation was photolabelled with 5-azido- $\mid{ }^{32}$ PJUDP-glucose and 5 - ${ }^{125}$ IASA-UDPglucose which bind covalently to the enzyme after UV irradiation. These UDP-glucose substrate analogues were competitive inhibitors of the enzyme with a $K_{\mathrm{i}}$ of $1.42 \mathrm{~mm}$ and $0.3 \mathrm{~mm}$ for 5-azido-UDP-glucose and 5-ASA-UDPglucose, respectively $\left(K_{\mathrm{m}}\right.$ for UDP-glucose $\left.=1.9 \mathrm{mM}\right)$. Potential UDP-glucose-binding polypeptides were identified with molecular masses of 31,50 and $115 \mathrm{kDa}$.
\end{abstract}

\section{Introduction}

$1,3-\beta$-Glucan is the main polysaccharide constituent of the cell wall of most fungal species (Wessels, 1986). Biosynthesis of fungal $1,3-\beta$-glucan is generally believed to be mediated by membrane-bound glycosyltransferases which use UDP-glucose (UDP-Glc) as a substrate. Although a glucan synthase activity has been detected in several fungi (Larriba \& Andaluz, 1991), a UDP-Glcbinding polypeptide responsible for the enzyme activity has not been isolated or even identified in the fungal kingdom.

Attempts to purify $1,3-\beta$-glucan synthase using membrane-dissociating agents followed by chromatographic or electrophoretic procedures have been unsuccessful for several reasons. The half-life of the activity of membrane preparations at $4{ }^{\circ} \mathrm{C}$ does not usually exceed a few hours (Szaniszlo et al., 1985). Moreover, glucan synthesis in fungi, as in plants, requires the participation of at least

\footnotetext{
*Author for correspondence. Tel. +3345688225 ; fax +334568 8420 .

Abbreviations: ADP-Glc, adenosine diphosphoglucose; 5-ASAUDP-Glc, 5(3-p) azido salicylamine allyl uridine diphosphoglucose; EB, glucan synthase extraction buffer; GDP-Glc, guanosine diphosphoglucose; GTP $\gamma \mathrm{S}$, guanosine $5^{\prime}\left(\gamma\right.$-thio) triphosphate; 5- $\mathrm{N}_{3}$-UMP, 5azido-uridine monophosphoglucose; 5- $\mathrm{N}_{3}$-UDP-Glc, 5-azido-uridine diphosphoglucose; 5- $\mathrm{N}_{3}$-UTP, 5-azido-uridine triphosphoglucose; RM, glucan synthase reaction mixture; UDP-Glc, uridine diphosphoglucose.
}

one catalytic and one regulatory subunit. Separation of one subunit from the other one will result in the suppression of glucan synthase activity (Kang \& Cabib, 1986).

Alternative approaches to purify the $\beta$-glucan synthase complexes have been reported. Differential centrifugation using glycerol or sucrose density gradients has been used with some success (Bulone et al., 1990; Dhugga \& Ray, 1991; Fink et al., 1990; Kamat et al., 1992). Electron microscopy and biochemical studies have demonstrated that the enzyme complex remains bound to the insoluble fibrils of glucan. These observations have led to another type of purification procedure based on a product entrapment method. Whereas this method has been particularly successful in the case of the 1,4- $\beta$ glucan synthase of Acetobacter xylinum (Lin et al., 1990 ), only partial purification has been achieved in the case of fungal or plant 1,3- $\beta$-glucan synthase (Awald et al., 1993; Bulone et al., 1990; Frost et al., 1990). Another approach has involved the use of polyclonal and monoclonal antibodies which have been most effective with peanut, Lolium and Pisum glucan synthases (Dhugga \& Ray, 1991; Fink et al., 1990; Kamat et al., 1992; Meikle et al., 1991).

Another strategy which has been developed is the use of affinity labelling with substrate analogues to identify the UDP-Glc-binding polypeptides in the synthase complex. The best probes developed to date are analogues of UDP-Glc in which the glucose residue is 
intact and the uridine residue is modified with a photoreactive group. The first of these probes to be used successfully was a 5-azido $\left[{ }^{32} \mathrm{P}\right] \mathrm{UDP}-\mathrm{Glc}\left(5-\mathrm{N}_{3}-\left[{ }^{32} \mathrm{P}\right] \mathrm{UDP}-\right.$ Glc; Drake et al., 1989). This compound has been used to label the catalytic subunit of plant and fungal $1,3-\beta$ glucan synthases and of the bacterial 1,4- $\beta$-glucan synthase (Frost et al., 1990, 1992; Lawson et al., 1989; Lin et al., 1990). More recently, K. Ng has synthesized a $5(3-p){ }^{125}$ I azido salicylamide allyl UDP-Glc (5- ${ }^{125}$ IASAUDP-Glc) which has been used in combination with monoclonal antibodies to identify a UDP-Glc-binding polypeptide present in the $\beta$-glucan synthase complex of Lolium multiflorum (Meikle et al., 1991).

We report here the characterization and solubilization of the 1,3- $\beta$-glucan synthase of the fungus Aspergillus fumigatus and the identification of a UDP-Glc-binding polypeptide by photoaffinity using the two substrate analogues 5-N $\mathrm{N}_{3}$-UDP-Glc and 5-ASA-UDP-Glc.

\section{Methods}

Culture conditions. A. fumigatus strain CBS 144-89 was maintained on $2 \%(\mathrm{w} / \mathrm{v})$ malt (Touzart \& Matignon, Paris) agar slants. Erlenmeyer flasks containing $50 \mathrm{ml}$ of Sabouraud liquid medium $(2 \%, \mathrm{w} / \mathrm{v}$, glucose and $1 \%, w / v$, Mycopeptone; Biokar, Paris) were inoculated and shaken for $3 \mathrm{~d}$ at $180-200$ r.p.m. at $25^{\circ} \mathrm{C}$. These precultures were then inoculated into a 2 litre Biolafitte fermenter containing 1.2 litres Sabouraud liquid medium. The culture conditions were as follows: temperature $25^{\circ} \mathrm{C}$, agitation 500 r.p.m., aeration 0.51 air $\mathrm{min}^{-1}$. After various growth times, the mycelium was collected by vacuum filtration on a Büchner funnel, extensively washed with water and dried under two pieces of filter paper.

Preparation of cell-free extracts. Mycelium was resuspended $(0.25 \mathrm{~g}$ wet wt $\mathrm{ml}^{-1}$ ) in $60 \mathrm{ml}$ 1,3- $\beta$-glucan synthase extraction buffer containing $50 \mathrm{~mm}$-Tris/ $\mathrm{HCl} \mathrm{pH} 7 \cdot 8,1 \mathrm{~mm}$-EDTA, $0 \cdot 2 \mathrm{M}-\mathrm{NaF}$ and $1 \mathrm{M}$-sucrose (EB). The homogenate was disrupted for $5 \mathrm{~min}$ in a $\mathrm{CO}_{2}$-cooled Braun MSK homogenizer with $1 \mathrm{~mm}$ glass beads. Complete breakage of the cells was assessed by phase contrast light microscopy. Cell walls were removed by centrifugation at $4000 \mathrm{~g}$ for $10 \mathrm{~min}$. The membrane fraction was recovered after centrifugation at $33000 \mathrm{~g}$ for $60 \mathrm{~min}$. The membrane pellet was resuspended in solubilization buffer containing $4 \mathrm{ml}$ EB with $12 \mathrm{mg}$ CHAPS (Sigma) and $20 \mu \mathrm{M}-\mathrm{GTP} \gamma \mathrm{S}$ (Boehringer Mannheim). After $20 \mathrm{~min}$ at $0^{\circ} \mathrm{C}$, the extract was centrifuged at $33000 \mathrm{~g}$ for $20 \mathrm{~min}$ and the supernatant was recovered and applied to a Bio-gel P30 column pre-equilibrated with EB containing $1.5 \mathrm{mg}$ CHAPS $\mathrm{ml}^{-1}$. GTP $\gamma \mathrm{S}(20 \mu \mathrm{M})$ was added to the void volume from the column. Preliminary experiments have shown that P30 chromatography stabilized the enzyme preparation without altering its activity. This extract (P30 fraction) was used as the source of enzyme. All fractionation procedures were carried out at $4{ }^{\circ} \mathrm{C}$. To avoid any loss in enzyme activity, all extracts were stored in liquid nitrogen.

The protein concentration of the extract was determined by the Coomassie brillant blue method (Bradford, 1976), using a Bio-Rad kit and BSA as the standard.

1,3- $\beta$-Glucan synthase assay. $\mathrm{P} 30$ extract $(40-170 \mu \mathrm{g}$ protein) was added to the reaction mixture (RM) containing EB, 3 mM-cellobiose, $3 \mathrm{~mm}$-glucose 6-phosphate, $3 \mathrm{~mm}$-sodium tartrate, $0 \cdot 1 \mathrm{~mm}-\mathrm{CaCl}_{2}, 2 \mathrm{mg}$ $\alpha$ amylase $\mathrm{ml}^{-1}$ and $2.5 \mathrm{~mm}$-UDP-Glc (containing $2.4 \mu \mathrm{m}$ UDP $\left[{ }^{14} \mathrm{C}\right]-$ glucose, specific activity $293 \mathrm{nCi}(10.8 \mathrm{kBq}) \mathrm{nmol}^{-1}$, Amersham) in a final volume of $25 \mu \mathrm{l}$. The assay was incubated for $30 \mathrm{~min}$ at $25^{\circ} \mathrm{C}$ and the reaction was stopped by the addition of $50 \mu \mathrm{l}$ ethanol. The resulting homogenate was filtered through a Whatman GF/C glass-fibre filter. The filter was then rinsed with $60 \mathrm{ml} 60 \%(\mathrm{v} / \mathrm{v})$ ethanol and placed in $4 \mathrm{ml}$ of scintillation fluid BCS (Amersham). Radioactivity was estimated in a LKB liquid scintillation counter. The specific activity of the glucan synthase was expressed as nmol UDP-Glc incorporated $\min ^{-1}(\mathrm{mg} \text { protein })^{-1}$.

Identification of 1,3- $\beta$-glucan synthase reaction product. The reaction product was characterized using an exo-1,3- $\beta$-glucanase [laminarinase from mollusc, $32 \mathrm{U}$ (g protein $)^{-1}$, Sigma], and an $\alpha$ amylase (Sigma) as described previously (Beauvais \& Latgé, 1989).

To elucidate the chemical nature of the linkages occurring between individual sugars, the reaction product was freeze-dried and incubated overnight at $105^{\circ} \mathrm{C}$ in the presence of hydrazine (Pierce). The de novo synthesized polysaccharide was recovered by ethanol precipitation, freeze-dried and permethylated. After methanolysis, free hydroxyl groups were acetylated and the position in which sugar residues were glycosylated was identified by GLC (Montreuil et al., 1986).

Characterization of 1,3- $\beta$-glucan synthase activity. Characterization of the glucan synthase was performed using P30 fractions from 17-hold mycelium. The role of each compound of the extraction buffer (sucrose, $\mathrm{NaF}$ and EDTA) was determined by removing each of these compounds separately from EB and RM. Optimal NaF concentration was determined with $P 30$ fractions and RM prepared with a range of $\mathrm{NaF}$ concentrations from 0 to $0.2 \mathrm{M}$. The influence of GTP was tested using a P30 fraction without addition of GTP $\gamma \mathrm{S}$.

$K_{\mathrm{m}}$ was determined by incubating in $\mathrm{RM}$ at $25^{\circ} \mathrm{C}$ for 10 min with different concentrations of UDP-Glc ranging from $0.25 \mathrm{~mm}$ to $1 \mathrm{~mm}$. Competition experiments by substrate analogues were performed by adding $0.34-0.68 \mathrm{~mm}-5$-ASA-UDP-Glc or $5-\mathrm{N}_{3}$-UDP-Glc to RM. Reactions in the presence of 5-ASA-UDP-Glc were carried out in darkness.

The role of uridine, uridine mono-, di-, or triphosphate and inorganic pyrophosphate on glucan synthase activity was assessed by addition of these compounds at $2.5 \mathrm{~mm}$ and $5 \mathrm{~mm}$ in RM. The specificity of UDPGlc as a substrate for glucan synthesis was investigated by adding ADP-Glc or GDP-Glc in RM containing $2.5 \mu \mathrm{m}$ UDP- $\left[{ }^{14} \mathrm{C}\right]$ glucose in the absence of non-radioactive UDP-Glc.

Photoaffinity labelling. 5- $\mathrm{N}_{3}-[2 \mathrm{P}] \mathrm{UDP}-\mathrm{Glc}$ was synthesized as described by Rudominsku \& Drake (1993) by a procedure slightly modified from Drake et al. (1989).

5-ASA-UDP-Glc was synthesized as previously described (Meikle et al., 1991). After iodination, mono and di-iodo derivatives were separated from 5-ASA-UDP-Glc by a modified procedure (K. Ng, unpublished) on PEI cellulose thin-layer chromatography developed with $1 \mathrm{M}-\mathrm{NH}_{4} \mathrm{HCO}_{3}$. The bands of PEI-cellulose corresponding to the labelled products (visualized by autoradiography) were recovered separately and eluted with $1 \mathrm{M}-\mathrm{NH}_{4} \mathrm{HCO}_{3}$. The $\mathrm{NH}_{4} \mathrm{HCO}_{3}$ was removed by repeated lyophilization.

The reaction mixture contained a total volume of $50 \mu \mathrm{l}$ with the probe and 40 to $150 \mu \mathrm{g}$ protein ( $\mathrm{P} 30$ fraction from 17-h-old mycelium) in a buffer with $50 \mathrm{~mm}$-Tris/HCl pH 7.8, 1 mm-EDTA, $200 \mathrm{~mm}-\mathrm{NaF}$, $1 \mathrm{~m}$-sucrose, $10 \mathrm{~mm}$-glucose 6-phosphate and 2 mM-cellobiose, $5-\mathrm{N}_{3}-\left[{ }^{32} \mathrm{P}\right]$ UDP-Glc was added at $50 \mu \mathrm{M}$ final concentration whereas 5- ${ }^{125}$ IASA-UDP-Glc was added at $5 \mu \mathrm{M}$ final concentration in the presence of $5 \mathrm{~mm}-\beta$-mercaptoethanol.

The reaction conditions for $5-\mathrm{N}_{3}-\left[^{32} \mathrm{P}\right]$ UDP-Glc were incubation for $30 \mathrm{~s}$ and UV irradiation for $90 \mathrm{~s}$ at $4{ }^{\circ} \mathrm{C}$ or room temperature and for 5- ${ }^{125}$ IASA-UDP-Glc incubation for $60 \mathrm{~s}$ and irradiation for $5 \mathrm{~min}$ at room temperature in the dark. A hand-held UV lamp was placed $2 \mathrm{~cm}$ above the sample. A wavelength of $254 \mathrm{~nm}$ is needed for $5-\mathrm{N}_{3}-\mathrm{UDP}$. Glc whereas similar labelling was observed with 5-ASA-UDP-Glc at 
254,312 or $356 \mathrm{~nm}$. Control labelling reactions were performed in the absence of UV irradiation or with probes pre-irradiated before addition to the reaction mixture. Reaction was terminated by the addition of $250 \mu 110 \%(\mathrm{w} / \mathrm{v}) \mathrm{TCA}$. After $15 \mathrm{~min}$ at $4{ }^{\circ} \mathrm{C}$, the mixture was centrifuged at 13000 r.p.m. for $5 \mathrm{~min}$ and the supernatant was carefully removed. The pellet was resuspended in a sample buffer containing $0 \cdot 25 \%$ (w/v) Tris $/ \mathrm{HCl} \mathrm{pH} \mathrm{8.0,3.72} \mathrm{M-urea,} 2.5 \%(\mathrm{w} / \mathrm{v})$ DTT and $5 \%$ $(\mathrm{w} / \mathrm{v})$ SDS. Electrophoresis was performed with 7.5 or $10 \%(\mathrm{w} / \mathrm{v})$ acrylamide gels according to Laemmli (1970). Labelled polypeptides were visualized by autoradiography at $-80^{\circ} \mathrm{C}$ using Kodak X-Omat$\mathrm{AR}$ or $\mathrm{K}$ film with a Cronex intensifying screen. Radioactivity was scanned using a Masterscan (Scanalytics).

The specificity of the photolabelling with the 5- $\mathrm{N}_{3}$-UDP-Glc and 5ASA-UDP-Glc probes was verified using two partially purified UDPGlc utilizing enzymes obtained from Sigma: UDP-glucose pyrophosphorylase and phosphorylase a. Labelling of unique polypeptides of 48 and $97 \mathrm{kDa}$, respectively, was observed with these two enzymes. No labelling was observed in the absence of UV irradiation. In the presence of UDP-Glc, photoincorporation was decreased.

\section{Results}

Characterization of the reaction product of the 1,3- $\beta$-glucan synthase assay

The glucan synthase reaction product was completely digested by laminarinase, but not degraded by $\alpha$-amylase. When the product of laminarinase digestion $(3 \mathrm{~h}$ at $37^{\circ} \mathrm{C}$ ) was run on silica gel plates, $64 \%$ of the solubilized radioactivity corresponded to glucose and $36 \%$ to laminaribiose. After methanolysis of the permethylated

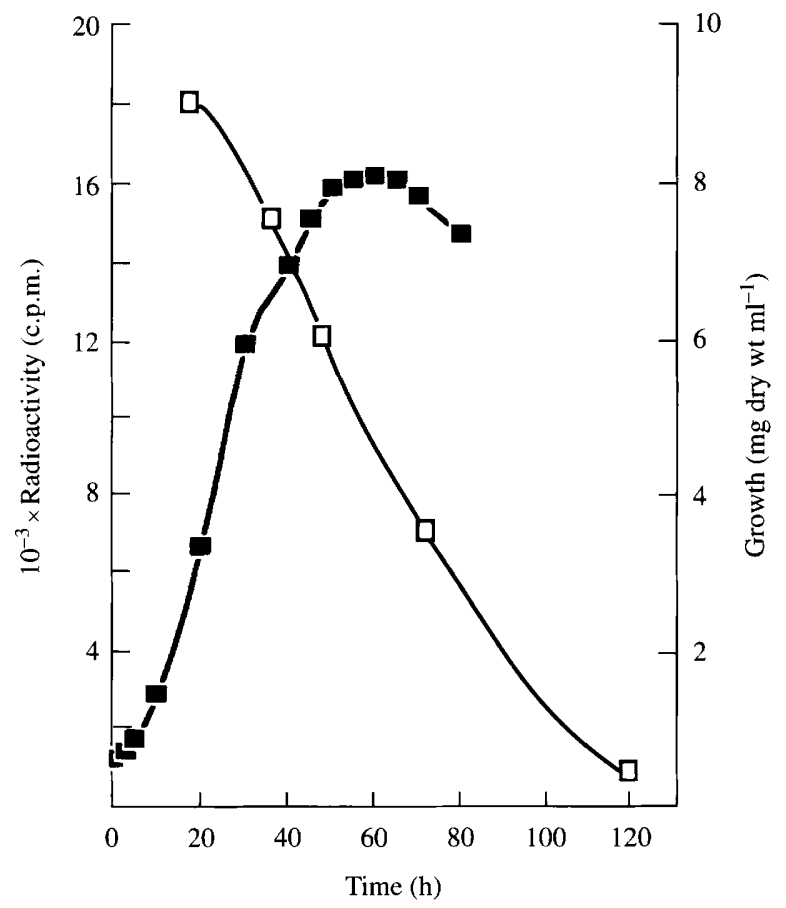

Fig. 1. Glucan synthase activity ( $\square$ ) during mycelial growth ( $\mathbf{a})$. The enzyme preparation (P30 fraction) was extracted after 17, 36, 48, 72 and $120 \mathrm{~h}$ of culture growth and incubated in RM at $24{ }^{\circ} \mathrm{C}$ for $30 \mathrm{~min}$ (P30 fraction: $100 \mu \mathrm{g}$ protein). glucan purified after hydrazinolysis of the reaction product, only 1,3-acetyl 2,4,6-methyl glucosides were identified by GLC. These results demonstrated that linear chains of $1,3-\beta$-glucan were the only polysaccharide synthesized by the P30 extract.

\section{Characterization of the glucan synthase of A. fumigatus}

Fig. 1 shows that the glucan synthase activity [14 nmol UDP-Glc $\mathrm{min}^{-1}$ (mg protein $)^{-1}$ ] was highest at the first time point (17-h-old culture) and declined thereafter. At $36 \mathrm{~h}, 48 \mathrm{~h}$ (maximal mycelial growth) and $120 \mathrm{~h}$ of culture, the activity was respectively $80 \%, 65 \%$ and $3 \%$ of that detected at $17 \mathrm{~h}$.

Incubation of membrane extracts with $0.3 \%$ CHAPS resulted in the solubilization of about $70 \%$ of the total proteins. In our extraction procedure, CHAPS-solubilized extracts contained $2-4 \mathrm{mg}$ protein $\mathrm{ml}^{-1}$. Increasing the solubilization time or the CHAPS concentration did not enhance protein solubilization. Moreover, CHAPS concentrations higher than $3 \mathrm{mg} \mathrm{ml}^{-1}$ caused a decrease in the glucan synthase activity. Before elution through the Bio-gel P30 column, the solubilized enzyme preparation was very unstable: $26 \%$ of the activity was lost after $20 \mathrm{~min}$ at $24^{\circ} \mathrm{C}$. In contrast, the fraction eluted in the void volume of the Bio-gel P30 column could withstand several freezing and thawing cycles without any loss of activity. A proportion $(50-70 \%)$ of the activity was recovered after storage of the $\mathrm{P} 30$ fraction for $16 \mathrm{~h}$ at $4{ }^{\circ} \mathrm{C}$. The glucan synthase activity of the P30 fraction reached $50-70 \%$ of the activity of the membrane extract recovered after the $33000 \mathrm{~g}$ centrifugation in the absence of any CHAPS treatment. P30 chromatography increased the activity of the CHAPS-solubilized extract since the activity of the fraction eluted in the void volume of the Bio-gel P30 column is $130 \%$ of the activity of the CHAPS extract loaded into the column. The presence of sucrose, $\mathrm{NaF}$ and EDTA in the extraction buffer was essential. Absence of sucrose or $\mathrm{NaF}$ in $\mathrm{EB}$ resulted in $80 \%$ and $72 \%$ loss of activity, respectively (Fig. 2). Highest activity was obtained with $0 \cdot 1-0 \cdot 2 \mathrm{M}-\mathrm{NaF}$. Removal of EDTA from EB caused $46 \%$ reduction in the glucan synthase activity (Fig. 2). Solubilization of the membrane proteins in the absence of GTP $\gamma \mathrm{S}$ resulted in a $40 \%$ decrease in the glucan synthase activity (Fig. 2).

Inorganic pyrophosphate $\left(\mathrm{PP}_{\mathrm{i}}\right)$ and uridine phosphate esters such as UTP, UDP or UMP added to the reaction mixture significantly reduced glucan synthase activity (Fig. 2). Uridine itself did not affect the enzyme activity (data not shown). At $2.5 \mathrm{~mm}, \mathrm{PP}_{\mathrm{i}}$ was the most effective inhibitor of glucan synthase. Inhibition levels observed with UMP, UDP and UTP were similar to other nucleotides such as ATP, ADP and GDP (data not shown). However, no incorporation of glucose into 


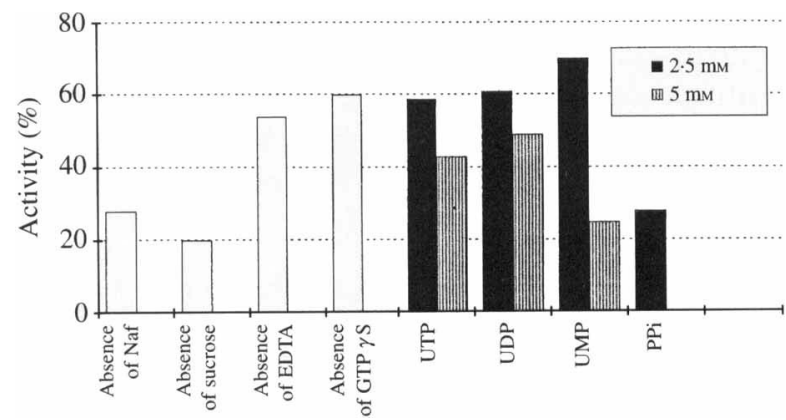

Fig. 2. Effect of various chemicals on the activity of $A$. fumigatus glucan synthase. Activity is expressed as percentage incorporation of $\left[{ }^{14} \mathrm{C}\right]$ glucose into $1,3-\beta$-glucans. Control in RM displaying $100 \%$ activity $\left[27 \mathrm{nmol} \mathrm{min}^{-1}(\mathrm{mg} \text { protein })^{-1}\right]$.

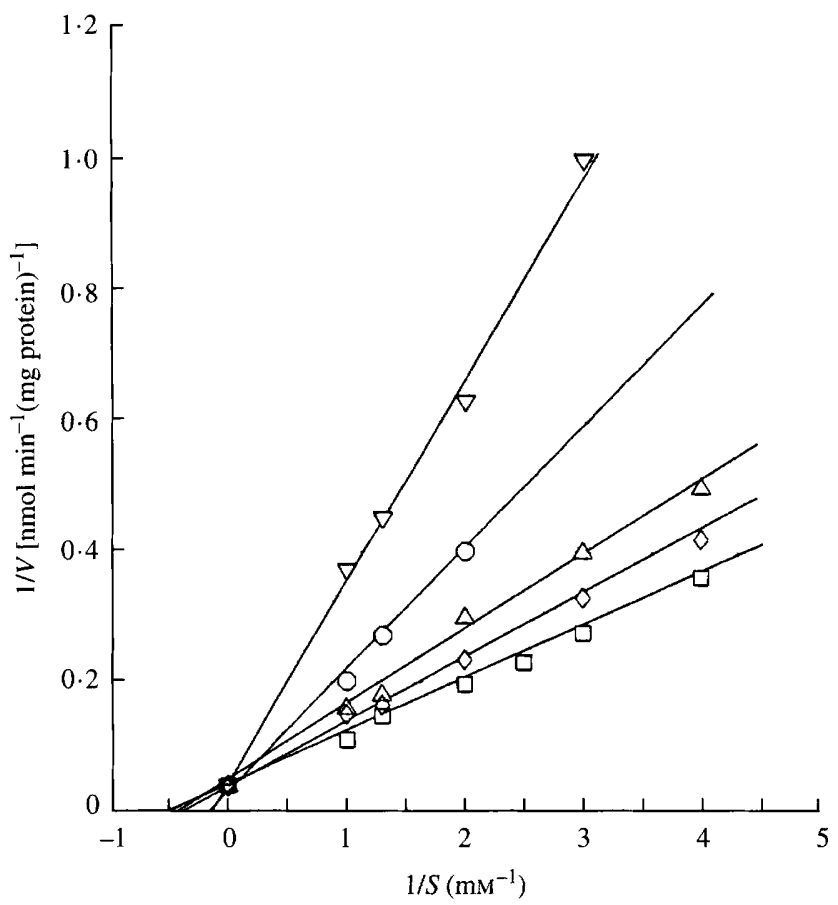

Fig. 3. Competitive inhibition of $\beta$-glucan synthase activity by 5-ASAUDP-Glc and 5- $\mathrm{N}_{3}$-UDP-Glc. The value for initial velocities at varying UDP-Glc $(0 \cdot 25-1 \mathrm{~mm},[])$, 5-ASA-UDP-Glc $(0.34 \mathrm{~mm}, O$; $0.68 \mathrm{~mm}, \nabla), 5-\mathrm{N}_{3}$-UDP-Glc $(0.34 \mathrm{mM}, \diamond ; 0.68 \mathrm{~mm}, \triangle)$ concentrations were obtained in a reaction mixture containing the P30 fraction $(169 \mu \mathrm{g}$ protein) and $2 \cdot 4 \mu \mathrm{M}$-UDP- $\left[{ }^{14} \mathrm{C}\right] \mathrm{Glc}$. Only reactions using 5-ASA-UDPGlc were carried out in the dark.

glucans, nor an inhibition of synthesis were obtained using ADP-Glc or GDP-Glc instead of UDP-Glc.

Glucan synthase incorporated glucose from UDP-Glc into acid-insoluble 1,3- $\beta$-glucan in an approximately linear fashion at $24^{\circ} \mathrm{C}$. The apparent $K_{\mathrm{m}}$ for UDP-Glc in the standard enzyme preparation, determined by using Michaelis-Menten plots, was $1.92 \mathrm{~mm}$ (Fig. 3). The substrate analogues 5-ASA-UDP-Glc and 5- $\mathrm{N}_{3}$-UDPGlc inhibited the activity in a competitive way (Fig. 3); the slope of double-reciprocal plots increased with

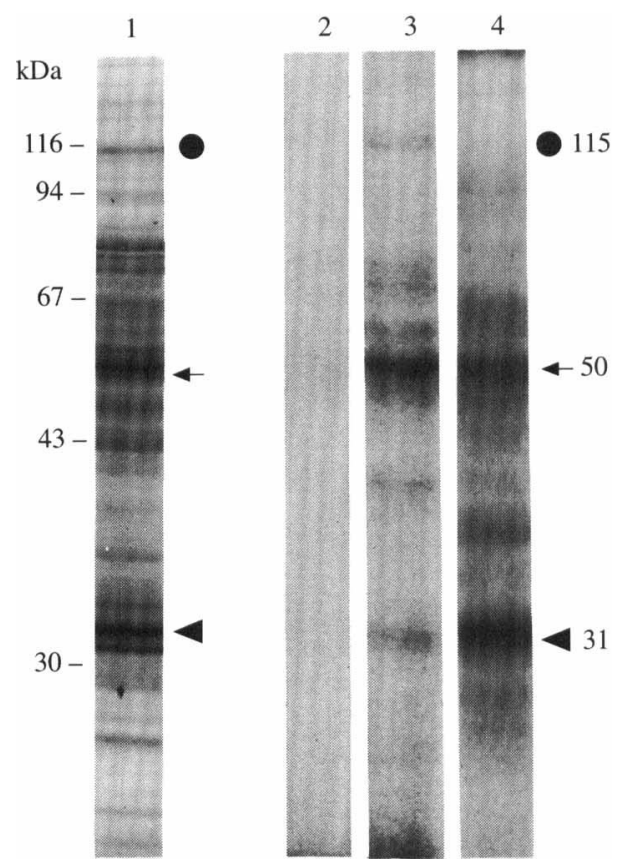

Fig. 4. Coomassie blue-stained $10 \%$ gel (lane 1) and its corresponding autoradiographs (lanes $2-4)$ of the $\mathrm{P} 30$ fraction $(40 \mu \mathrm{g}$ protein per lane). Lanes 2 and 3, photolabelling using 5- $\mathrm{N}_{3}\left[{ }^{32} \mathrm{P}\right] \mathrm{UDP}-\mathrm{Glc}$. Lane 4 : photolabelling using $5-{ }^{125}$ IASA-UDP-Glc. The reaction mixture not illuminated with UV light is shown in lane 2.

increasing concentration of the analogues without change in $V_{\max }$. The apparent $K_{\mathrm{i}}$ was $0.3 \mathrm{~mm}$ for 5-ASAUDP-Glc which was five times more effective than $5-\mathrm{N}_{3}-$ UDP-Glc $\left(K_{\mathrm{i}}=1.42 \mathrm{~mm}\right)$ (Fig. 3). The affinity of the enzyme for 5-ASA-UDP-Glc was 5 times higher than for $5-\mathrm{N}_{3}$-UDP-Glc.

\section{Photolabelling of the P30 fraction}

Fig. 4 shows representative autoradiographs of the CHAPS-solubilized (P30) membrane polypeptides labelled by the two probes $5-\mathrm{N}_{3}-\left[{ }^{32} \mathrm{P}\right] \mathrm{UDPG}$ and $5-{ }^{125}$ IASAUDP-Glc.

Two polypeptides with molecular masses of $31 \mathrm{kDa}$ and $115 \mathrm{kDa}$ were consistently labelled with $5-\mathrm{N}_{3}$ $\left[{ }^{32} \mathrm{P}\right] U D P-G l c$. Labelling of the other polypeptides, especially the $50 \mathrm{kDa}$ polypeptide, was not seen in all experiments. One of the labelled polypeptides $(64 \mathrm{kDa})$ is attributed to phosphoglucomutase (see Discussion). The reasons for this variability in the labelling pattern were not explored.

The $31 \mathrm{kDa}$ and $50 \mathrm{kDa}$ polypeptides were most prominently labelled with 5-125IASA-UDP-Glc (Fig. 4). The labelled protein at $35 \mathrm{kDa}$ was not always observed in other labelling experiments. In contrast to photolabelling with $5-\mathrm{N}_{3}-\left[{ }^{32} \mathrm{P}\right] \mathrm{UDP}-\mathrm{Glc}$, the $64 \mathrm{kDa}$ and $115 \mathrm{kDa}$ polypeptides were not labelled with 5- ${ }^{125}$ IASA- 

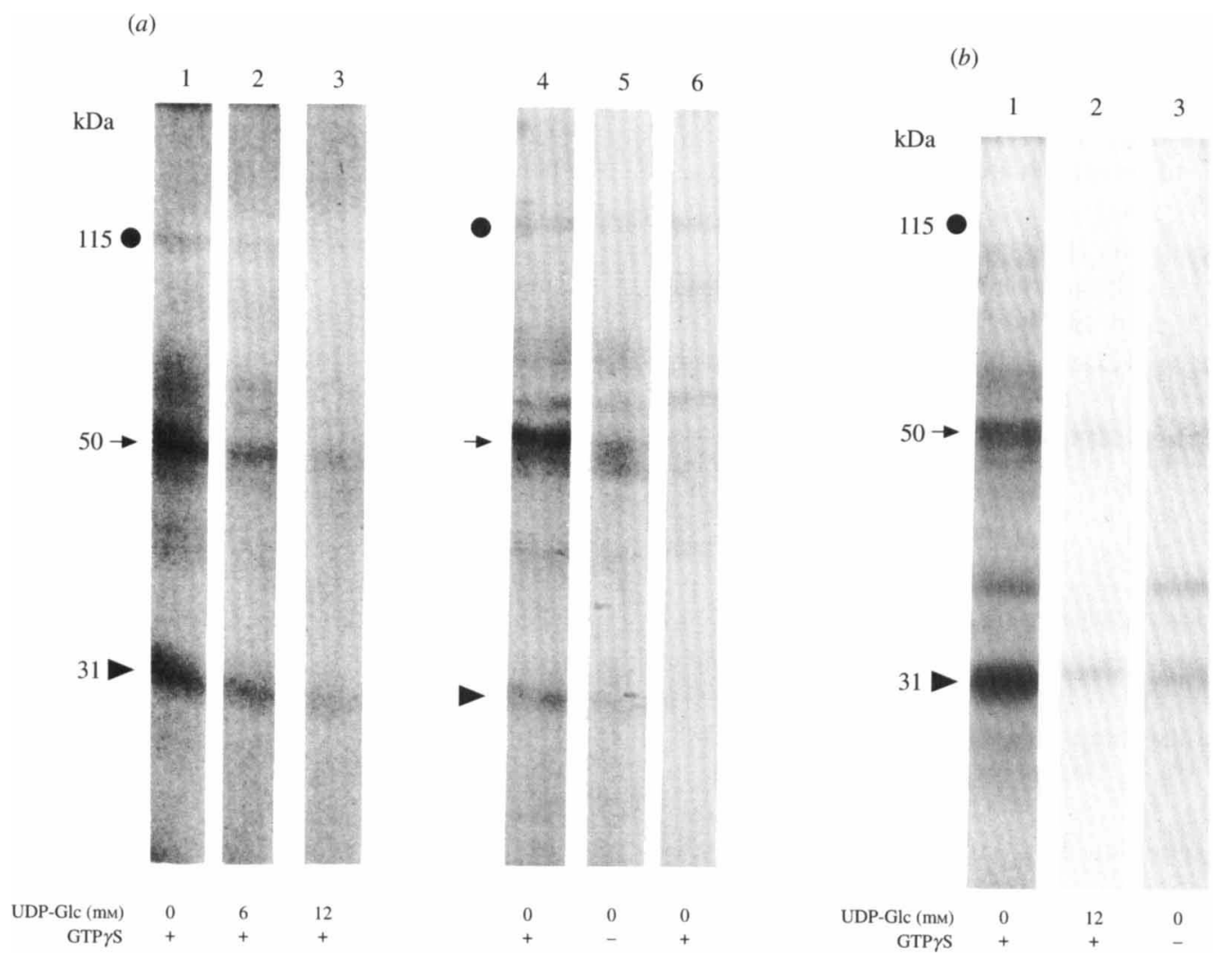

Fig. 5. Inhibition of photolabelling with 5- $\mathrm{N}_{3}-\left[{ }^{32} \mathrm{P}\right]$ UDP-Glc $(a)$ and 5-[25I]ASA-UDP-Glc $(b)$. P30 fraction (17-h-old mycelium) was photolabelled in the presence of increasing UDP-Glc concentrations ( $0 \mathrm{~mm}$, lanes $a 1, b 1 ; 6 \mathrm{~mm}$; lane $a 2 ; 12 \mathrm{~mm}$, lanes $a 3, b 2)$, or in the presence (lanes $a 4, b 1$ ) or absence of GTP $y \mathrm{~S}$ (lanes $a 5$ and $b 3$ ). Lane $a 6, \mathrm{P} 30$ fraction from a 5-d-old mycelium.

UDP-Glc. All bands labelled with the probes could be identified in a protein-stained acrylamide gel (Fig. 4). In P30 fractions with low glucan synthase activity (5-d-old mycelium), the 31 and $50 \mathrm{kDa}$ bands appeared faint in protein-stained gels and were not labelled by both probes. In contrast, labelling could be seen at the level of the $115 \mathrm{kDa}$ band (Fig. 5).

Competition experiments showed that in the presence of increasing concentrations of UDP-Glc in the photolabelling reaction mixture, the intensity of all labelled bands was inhibited with the two probes but was never totally abolished even at $12 \mathrm{~mm}$-UDP-Glc (Fig. 5). The inhibition level was calculated by scanning the bands labelled by the two radioactive probes. In the presence of $6 \mathrm{~mm}$-UDP-Glc, the labelling of the 31,50 and $115 \mathrm{kDa}$ bands detected by $5-\mathrm{N}_{3}-[2 \mathrm{P}] \mathrm{PDP}-\mathrm{Glc}$ was inhibited by 41,31 and $25 \%$, respectively. After addition of $12 \mathrm{~mm}-$ UDP-Glc, inhibition reached 66,64 and $100 \%$, respectively, for the 31,50 and $115 \mathrm{kDa}$ bands. After addition of 5-ASA-UDP-Glc $(0.05 \mathrm{~mm})$ the labelling of all bands was completely abolished (data not shown). After addition of $12 \mathrm{~mm}$-UDP-Glc, the labelling of the 31 and $50 \mathrm{kDa}$ polypeptides identified by $5-^{125}$ IASAUDP-Glc was inhibited by 25 and $43 \%$, respectively.
These results confirmed the inhibition kinetics studies (Fig. 3) and showed that 5-ASA-UDP-Glc has a higher affinity for the glucan synthase than the substrate UDPGlc and its analogue 5- $\mathrm{N}_{3}$-UDP-Glc.

In absence of GTP $\gamma \mathrm{S}$ the labelling of the 31,50 and $115 \mathrm{kDa}$ bands with $5-\mathrm{N}_{3}-\left[{ }^{32} \mathrm{P}\right] U D P-G l c$ and of the 31 and $50 \mathrm{kDa}$ bands with $5-{ }^{125}$ IASA-UDP-Glc was selectively inhibited (Fig. 5). These extracts had a low glucan synthase activity (Fig. 2). In contrast, the presence of non-competitive inhibitors of enzyme activity like cilofungin or $\mathrm{NaCl}$, did not decrease photolabelling (data not shown).

\section{Discussion}

$1,3-\beta$-Glucan synthase activity has been detected in plants and fungi. In plants, glucan synthase is a repair enzyme which is activated under condition of stress such as mechanical damage or pathogen invasion (Delmer et al., 1991). In fungi, it is responsible for the synthesis of the main constituent of the fungal wall and is essential for growth. Both plant and fungal enzymes are membranous and can be solubilized by detergents such as digitonin, octylglucoside or CHAPS (Fevre, 1979; Frost 
et al., 1992; Hayashi et al., 1987; Quigley et al., 1988; Lawson et al., 1989). No glucan synthase has been isolated until now.

In $A$. fumigatus, five factors appear to be essential for an optimal glucan synthase activity, namely the age of the culture, GTP, NaF, sucrose and EDTA. Ageing of the mycelium could be accompanied by an increase in the fragility of the membranes or in the amount or specificity of cytosolic proteases which could perturb intact glucan synthase recovery after cell breakage. However, a decrease of glucan synthase activity during growth is not usually the rule amongst fungi. For example, the enzyme activity of CHAPS-solubilized extracts from the zygomycetous Entomophaga aulicae increases during the mycelial growth phase (A. Beauvais, unpublished data).

The requirement of GTP for maximal activity is a common property of this fungal enzyme which has been studied in several species belonging to different taxonomic groups (Cabib \& Kang, 1987; Szaniszlo et al., 1985). The results obtained with other fungi suggest that the glucan synthase complex consists of at least two subunits: a regulatory GTP-binding subunit and a catalytic UDP-Glc-binding subunit (Kang \& Cabib, 1986). In $A$. fumigatus glucan synthase biochemical studies and labelling experiments with substrate analogues confirmed the essential role of GTP: the selective inhibition of the photolabelling due to the removal of GTP $\gamma \mathrm{S}$ would suggest that GTP mediates UDP-Glc binding in the catalytic subunit. The roles of osmotic stabilizer (sucrose or glycerol), phosphatase inhibitor $(\mathrm{NaF})$, disaccharide (cellobiose) or metal chelators (EDTA) vary between membrane preparations of the different fungal species studied (Beauvais \& Latgé, 1989; Cabib \& Kang, 1987; Cerenius \& Söderhäll, 1984; Larriba et al., 1981; Orlean \& Ward, 1983; Quigley et al., 1988). However, in the absence of any purified enzyme, the role of all these additives cannot be precisely assessed.

Although both plant and fungal 1,3- $\beta$-glucan synthases have not been sufficiently characterized, these enzymes seem to belong to different protein families, due to differences in cofactor or activator requirements. In contrast to fungal enzymes, plant enzymes require divalent $\mathrm{Ca}^{2+}$ and $\mathrm{Mg}^{2+}$ but do not need GTP for activation. Furfuryl glucoside, which stimulates the glucan synthase of mung bean at least 20-fold (Ohana et al., 1992), has a very low effect $(29 \%)$ on A. fumigatus glucan synthase (data not shown).

Because of the instability of all glucan synthase preparations and the necessity of a probable multimeric complex to obtain the activity, the use of UDP-Glc analogues able to bind covalently to the UDP-Glcbinding polypeptides seems to be the best chemical approach to identify the catalytic subunit of glucan synthase. Amongst all probes used to label plant or bacterial 1,3- $\beta$ - and 1,4- $\beta$-glucan synthases, three substrate analogues [ $\left[{ }^{32} \mathrm{P}\right]$ UDP-Glc, $5-\mathrm{N}_{3}-\left[{ }^{32} \mathrm{P}\right] \mathrm{UDP}-\mathrm{Glc}$, and 5- ${ }^{125}$ IASA-UDP-Glc seem the most appropriate markers of the UDP-Glc binding domain. All these probes apparently form covalent bonds with amino acids at the binding site after UV irradiation. The exact mechanism of photolabelling with $\left[{ }^{32} \mathrm{P}\right]$ UDP-Glc is not clear. A longer UV exposure time ( $20 \mathrm{~min})$ is required than with azidoanalogues $(1-5 \mathrm{~min})$. It is suggested that upon irradiation, free radicals can be generated from the uracil moiety of UDP-Glc or from an aromatic amino acid in the active site of the protein to form covalent bonds between UDP-Glc and UDP-Glc-binding polypeptide (Delmer et al., 1991).

The photoreactivity of 5- $\mathrm{N}_{3}$-UDP-Glc and 5-ASAUDP-Glc is due to the azido function which forms a highly reactive short lived nitrene intermediate upon UV irradiation. In the case of $A$. fumigatus glucan synthase, the $K_{\mathrm{i}}$ value for 5-ASA-UDP-Glc was lower than that obtained with 5- $\mathrm{N}_{3}$-UDP-Glc. These results are in agreement with previous studies (Frost et al., 1990; Meikle et al., 1991) and confirm that the affinity of the substrate analogue for its enzyme site is directly dependent upon the hydrophobicity of the probe. However, the binding is due not just to the hydrophobicity of the analogue but also to a direct interaction of the ASA group on the uridine $\mathrm{C}-5$ position with an amino acid on the binding site $(\mathrm{K} . \mathrm{Ng}$, unpublished data). Our comparative study with 5- $\mathrm{N}_{3}$-UDP-Glc and 5ASA-UDP-Glc on the same enzyme preparation confirms that both substrate analogues can compete efficiently for the same enzymic site. Nevertheless, the use of 5-ASA-UDP-Glc requires the addition of $5 \mathrm{~mm}$ mercaptoethanol to avoid a non-specific labelling of numerous proteins (data not shown). The highly nucleophilic thiol group of mercaptoethanol apparently forms unreactive photolysed products with intermediate longlived reactive species produced by irradiation of 5-ASAUDP-Glc which are responsible for non-specific binding of proteins (Meikle et al., 1991).

In some experiments with 5- $\mathrm{N}_{3}-\left[{ }^{32} \mathrm{P}\right] U D P-G l c$, a polypeptide of $64 \mathrm{kDa}$ was labelled. This band was mostly seen in the absence of glucose 6-phosphate and also with pre-irradiated probe. This was consistent with the property of the phosphoglucomutase (Drake et al., 1989). Labelling of proteins with a similar apparent molecular mass has also been detected in other plant systems (Lawson et al., 1989).

When the P30 fraction was incubated with $5-\mathrm{N}_{3}$ $\left[{ }^{32} \mathrm{P}\right]$ UDP-Glc or 5- ${ }^{125}$ IASA-UDP-Glc in the presence of increasing concentrations of unlabelled UDP-Glc, photolabelling of all polypeptides decreased. However complete inhibition was not obtained even at $12 \mathrm{~mm}$-UDPGlc. Unfortunately, a concentration of NDP sugars 
above $12 \mathrm{~mm}$ would have interfered with UV light penetration. For example, high levels of uridine (100 mM) which do not affect glucan synthase activity reduced the photolabelling obtained with both probes (data not shown). Using the same $5-\mathrm{N}_{3}-\left[{ }^{32} \mathrm{P}\right] U D P-G l c$ probe, Frost et al. (1990) have seen only a partial abolition of the labelling of the Beta vulgaris callose synthase in the presence of UDP-Glc. For the probe 5-ASA-UDP-Glc, the $K_{\mathrm{i}}$ was sixfold lower (and even more for the iodinated 5-ASA-UDP-Glc), than the $K_{\mathrm{m}}$ for UDP-Glc. Thus a complete inhibition would not be expected at these UDP-Glc concentrations. Similar results have also been reported by Meikle et al. (1991) with the same probe and Lolium multiflorum glucan synthase.

UDP, UMP, UTP and, in the case of 5-ASA-UDPGlc, PPi were also good inhibitors of the photolabelling (data not shown). All these compounds inhibited the glucan synthase activity of $A$. fumigatus to differing extents. Inhibition of other UDP-Glc-binding polypeptides and of UDP-Glc pyrophosphorylase with these compounds has been reported previously (Drake et al., 1989; Meikle et al., 1991). In contrast, glucose does not have any inhibitory effect. These results suggest that UDP-Glc-binding polypeptides recognize the phosphorylated uridine part of the UDP-Glc molecule.

In the plant kingdom, polypeptides labelled with UDP-Glc analogues or with antibodies belong to two families of protein with molecular masses in the range of 30 and $55 \mathrm{kDa}$. The $30 \mathrm{kDa}$ family includes the 30 and $31 \mathrm{kDa}$ proteins of Italian ryegrass, a $31 \mathrm{kDa}$ protein from soybean and a $34 \mathrm{kDa}$ protein from cotton (Meikle et al., 1991; Fink et al., 1990; Delmer et al., 1991). The $55 \mathrm{kDa}$ family contains a doublet with molecular mass of 54 and $58 \mathrm{kDa}$ in Italian ryegrass, a $57 \mathrm{kDa}$ protein in both carrot and red beet, a $52 \mathrm{kDa}$ protein in cotton and a $55 \mathrm{kDa}$ protein from pea (Delmer et al., 1991; Dhugga \& Ray, 1991; Frost et al., 1990; Lawson et al., 1989; Meikle et al., 1991). Two proteins labelled from $A$. fumigatus of 31 and $50 \mathrm{kDa}$ are in the same molecular mass range. As in cotton (Delmer et al., 1991) some variable labelling of the $50 \mathrm{kDa}$ protein in A. fumigatus was obtained (Fig. 4). Frost et al. (1990) showed that the photolabelling of callose synthase UDP-Glc-binding polypeptides from Beta vulgaris by $5-\mathrm{N}_{3}-[2 \mathrm{P}] \mathrm{UDP}-\mathrm{Glc}$ was greatly influenced by $\mathrm{pH}$. A similar result has been observed in the Lolium system using 5-ASA-UDP-Glc; the binding of the probe and catalysis had different $\mathrm{pH}$ optima (5.5 and 7.5 respectively) (K. $\mathrm{Ng}$, unpublished data). These results indicated that slight variations in extraction procedure or reaction conditions may be responsible for different photoinsertion results.

UDP-Glc-binding proteins with higher molecular masses $(83-84 \mathrm{kDa})$ have been also identified in cotton and in the cellulose synthesizing bacterium Acetobacter xylinum (Delmer et al., 1991; Lin et al.,1990). A high molecular mass $(115 \mathrm{kDa})$ band in A. fumigatus membrane extracts was also labelled. Thus UDP-Glc analogues usually label more than one protein in fungal or plant membrane preparations. This is in agreement with the presence of several subunits with different functions in 1,3$\beta$ - or 1,4- $\beta$-glucan synthase complexes. However further purification will be required together with photolabelling to identify the catalytic subunit of the A. fumigatus glucan synthase since other UDP-Glc-binding proteins could be present in the membrane preparations. The use of two structurally different analogues which detect a set of similar proteins $(31 \mathrm{kDa}, 50 \mathrm{kDa})$ highlights the usefulness of probing our impure enzyme with different photoreactive analogues of UDP-Glc. Moreover, product entrapment or differential centrifugation using sucrose density gradients did not increase the intensity of any bands after Coomassie staining whereas it increased glucan synthase specific activity (data not shown). The labelled proteins can now be electroeluted and sequenced, so that the amino acid sequence data can be checked against the databank of proteins to see if they are unique and if they are a good candidate for the catalytic subunit of 1,3- $\beta$-glucan synthase.

The authors thank E. Cabib for helpful comments at the beginning of the work and for carefully reading the manuscript.

\section{References}

Awald, P., Zugel, M., Monks, C., Frost, D. \& Selitrennikoff, C. P. (1993). Purification of 1,3- $\beta$-glucan synthase from Neurospora crassa by product entrapment. Experimental Mycology 17, 130-141.

Beauvais, A. \& Latgé, J. P. (1989). Chitin and $\beta(1-3)$ glucan synthases in protoplastic Entomophthorales. Archives of Microbiology 152, 229-236.

BRADFORD, M. M. (1976). A rapid and sensitive method for the quantification of microgram quantities of protein utilizing the principle of protein-dye binding. Analytical Biochemistry 72, $248-254$

Bulone, V., Girard, V. \& Fèvre, M. (1990). Separation and partial purification of 1,3- $\beta$-glucan and 1,4- $\beta$-glucan synthases from Saprolegnia. Plant Physiology 94, 1748-1755.

CABIB, E. \& KanG, M. S. (1987). Fungal 1,3- $\beta$-glucan synthase Methods in Enzymology 138, 637-642.

CERENIUS, L. \& SöDERHÄLL, K. (1984). Isolation and properties of $\beta$ glucan synthetase from the aquatic fungus, Aphanomyces astaci. Physiologia Plantarum 60, 247-252.

Delmer, D. P., Solomon, M. \& Read, S. M. (1991). Direct photolabeling with ${ }^{32}$ PJUDP-glucose for identification of a subunit of cotton fiber Callose synthase. Plant Physiology 95, 556-563.

DhugGa, K. S. \& RAY, P. M. (1991). A 55 kDa plasma membraneassociated polypeptide is involved in $\beta$-1,3-glucan synthase activity in pea tissue. FEBS Letters 278, 283-286.

Drake, R. R., Evans, R. K., Wolf, M. J. \& Haley, B. E. (1989). Synthesis and properties of 5-azido-UDP-glucose. Journal of Biological Chemistry 264, 11928-11933.

FèvRE, M. (1979). Digitonin solubilization and protease stimulation of $\beta$ glucan synthetases of Saprolegnia. Zeitschrift für Pflanzenphysiologie 95-S, 129-140.

Fink, J., Jebl.ICK, W. \& Kauss, H. (1990). Partial purification and immunological characterization of 1,3- $\beta$-glucan synthase from suspension cells of Glycine max. Planta 181, 343-348. 
Frost, D. J., Read, S. M., Drake, R. R., Haley, B. E. \& Wasserman, B. P. (1990). Identification of the UDP-glucose-binding polypeptide of callose synthase from Beta vulgaris L. by photoaffinity labeling with 5-azido-UDP-glucose. Journal of Biological Chemistry 265, $2162-2167$.

Frost, D. J., Drake, R. R. \& Wasserman, B. P. (1992). (1,3)- $\beta$-Glucan synthase from Saccharomyces cerevisiae: in vitro activation by $\beta$ lactoglobulin or Brij-25, and photoaffinity labeling of enriched microsomal fractions with 5-azido-UDP-Glc and 8-azido-GTP. Current Microbiology 24, 295-300.

Hayashi, T., Read, S. M., Bussel, J., Thelen, M., Lin, F.-C., Brown, R. M. \& Delmer, D. P. (1987). UDP-glucose:(1-3)- $\beta$-glucan synthases from mung bean and cotton. Plant Physiology 83, 1054-1062.

Kamat, U., Garg, R. \& Sharma, C. B. (1992). Purification to homogeneity and characterization of a 1,3- $\beta$-glucan (callose) synthase from germinating Arachis hypogaea cotyledons. Archives of Biochemistry and Biophysics 298, 731-739.

KANG, M. S. \& CABIB, E. (1986). Regulation of fungal cell wall growth: a guanine nucleotide-binding, proteinaceous component required for activity of (1-3)- $\beta$-D-glucan synthase. Proceedings of the National Academy of Sciences of the United States of America 83, 5808-5812.

LAEMmLI, U. K. (1970). Cleavage of structural proteins during the assembly of the head of bacteriophage T4. Nature, London 227 , 680-685.

LaRriba, G. \& ANDaluz, E. (1991). Biosynthesis of yeast glucan. In Fungal Cell Wall and Immune Response, pp. 49-68. Edited by J. P. Latgé \& D. Boucias. Heidelberg: Springer-Verlag.

Larriba, G., Morales, M.\& Ruiz-Herrera, J. (1981). Biosynthesis of $\beta$-glucan microfibrils by cell-free extracts from Saccharomyces cerevisiae. Journal of General Microbiology 124, 375-383.

Lawson, S. G., Mason, T. L., Sabin, R. D., Sloan, M. E., Drake, R. R., Haley, B. E. \& Wasserman, B. P. (1989). UDP-glucose:(1-
3)- $\beta$-glucan synthase from Daucus carota L. Plant Physiology 90, 101-108.

Lin, F, C., Brown, R. M., Drake, R. R. \& Haley, B. E. (1990). Identification of the uridine $5^{\prime}$-diphosphoglucose (UDP-Glc) binding subunit of cellulose synthase in Acetobacter xylinum using the photo affinity probe 5-azido-UDP-Glc. Journal of Biological Chemistry 265, $4782-4784$

Meikle, P. J., NG, K. F., Johnson, E., Hoogenraad, N. T. \& Stone, B. A. (1991). The $\beta$-glucan synthase from Lolium multiflorum. Journal of Biological Chemistry 266, 22569-22581.

Montreuil, J., Bouquelet, S., Debray, H., Fournet, B., Sitk, G. \& StreCKer, G. (1986). Glycoprotein. In Carbohydrate Analysis, a Practical Approach, pp. 143-204. Edited by M. F. Champlin \& J. F. Kennedy. Oxford: IRL Press.

Ohana, P., Delmer, D. P., Volman, G., Steffens, J. C., Matthews, D. E. \& Benziman, M. (1992). $\beta$-Furfuryl- $\beta$-glucoside: an endogenous activator of higher plant UDP-glucose:(1-3)- $\beta$-glucan synthase. Plant Physiology 98, 708-715.

Orlean, P. A. B. \& WARD, S. M. (1983). Sodium fluoride stimulates (1-3)- $\beta$-D-glucan synthase from Candida albicans. FEMS Microbiology Letters 18, 31-35.

Quigley, D. R., Hrmova, M. \& SelitrennikofF, P. (1988). $\beta(1-3)$ Glucan synthase of Neurospora crassa: solubilization and partial characterization. Experimental Mycology 12, 141-150.

Radominska, A. \& DraKe, R. R. (1993). Synthesis and uses of azidonucleoside diphosphate sugar photoaffinity analogs. Methods in Enzymology 230, (in the Press).

Szaniszlo, P. J., Kang, M. S. \& Cabib, E. (1985). Stimulation of $\beta(1-$ $3)$ glucan synthetase of various fungi by nucleoside triphosphates: generalized regulatory mechanism for cell wall biosynthesis. Journal of Bacteriology 161, 118-1194.

Wessels, J.G. H. (1986). Cell wall synthesis in apical growth International Review of Cytology 104, 37-97. 